\title{
Gairah Spiritual Kelompok Urban Sufisme di Tengah Maraknya Wabah Covid-19
}

\author{
M. Nanda Fauzan \\ ${ }^{1}$ UIN Sultan Maulana Hasanuddin Banten \\ e-mail: muhammadnandafauzan@gmail.com
}

\begin{abstract}
ABSTRAK. Urbanisasimembawa pola spritiual baru yang khas bagi masyarakat perkotaan, dan berbeda dengan tipologi masyarakat desa. Julia Howell memperkenalkan temuannya yang berkaitan dengan karakter spiritual tersebut, dan disebut sebagai sufisme urban. Yang menarik, temuan tersebut seolah membuktikan bahwa gejala spiritual selalu bermutasi di tiap zaman dan sejalan dengan masalah mutakbir. Urban sufisme labir sebagai jawaban atas merebaknya industrialisasi di wilayah perkotaan. Artikel ini dibuat untuk menggambarkan sejauh mana pola negosiasi dan gairah spiritual masyarakat perkotaan di tengah merebaknya wabah Covid-19. Penelitian ini dibuat dengan menggunakan metode kualitatif, dengan proses pengumpulan data berupa kajian pustaka. Hasil dari penelitian menunjukkan bahwa akses terhadap informasi dan komunikasi justru menjadi privilage yang membuat masyarakat ini akan tetap bisa melangsungkan aktivitas keagamaan mereka di ranah virtual.
\end{abstract}

Kata kunci: masyarakat kota, urban sufisme, wabah Covid-19.

\section{PENDAHULUAN}

Desa merupakan simbol homogenitas budaya, maka kota melambangkan heterogenitas kebudayaan; tempat di mana berbagai manusia berkumpul atas dasar kepentingan yang berbeda. Dengan demikian, kota dicirikan oleh beragam orang, agama, dan etnis. Ada banyak variasi dalam polah keseharian mereka. Seperti kebiasaan makan, kebiasaan berpakaian, kondisi kehidupan, kepercayaan agama, pandangan budaya, adat istiadat, dan tradisi penduduknya.

Istilah 'komunitas' digunakan oleh sosiolog untuk menggambarkan kualitas hubungan yang menghasilkan identitas kebersamaan yang kuat di antara orang-orang yang tinggal dan menetap di wilayah geografis tertentu. Mereka menggambarkan pedesaan sebagai 'komunitas' sementara perkotaan sebagai 'masyarakat'. Hal ini disebabkan karena, di Desa, penduduk terikat secara personal dan saling mengenal satu sama lain, sementara di kota pola interaksi terasa sangat individualistik. Wirth (1938) membedakan masyarakat perkotaan dari masyarakat pedesaan, dalam tiga ciri utama: ukuran populasi, kepadatan, dan heterogenitas. Karakteristik ini berarti bahwa meskipun penduduk kota memiliki potensi lebih banyak kontak manusia daripada penduduk di pedesaan, mereka juga akan merasa lebih terisolasi karena sifat interaksi mereka yang kosong secara emosional.

Menurut Wirth, interaksi sosial, impersonal, segmental (lingkupnya sempit), dangkal, sementara, dan biasanya murni atas kebutuhan praktis. Dia menggambarkan ini sebagai kontak 'sekunder' yang sama sekali berbeda dari kontak 'primer' di daerah 
pedesaan.Sosiolog berkebangsaan Jerman, Ferdinand Toennies, menggunakan istilah 'gemeinschaft dan gessellschaft', yakni solidaritas 'mekanis dan organik' untuk menggambarkan karakteristik masyarakat pedesaan dan perkotaan berdasarkan pada kepentingan terjalinnya interaksi.

Komunitas pedesaan masuk dalam tipe gemenschaft (mekanik) sebab dicirikan oleh dominasi hubungan primer yang intim dan dengan penekanan pada tradisi, konsensus, dan informalitas. Perilaku sosial didasarkan pada ikatan pribadi yang erat dari kekerabatan. Di sisi lain, masyarakat perkotaan termasuk dalam gesellschaft (organik). Sebab, hubungan sosial bersifat formal, kontraktual, dan terspesialisasi. Masyarakat perkotaan memiliki konsep kolektifitas yang lemah dan menekankan pada tujuan utilitarian dan sifat hubungan sosial yang impersonal dan kompetitif. Dengan begitu, perilaku beragama masyarakat urban memiliki ciri khas yang timpang dan sangat tajam dengan masyarakat rural. Baik dalam aspek mahdah dan ghairu mahdah, maupun ibadah sosial dan personal. Tata ruang wilayah urban dengan kompleksitas tinggi membuat pola beribadah mereka cenderung mengutamakan hal-hal yang sifatnya langsung kepada Tuhan (Habluminallah), alih-alih kepada sesama manusia (Habluminanas). Sebab, selain intensitas interaksi yang minim, salah satu kendala masyarakat urban adalah hadirnya perasaan terasing (aliemasi).

Datangnya bencana wabah yang membuat kehidupan menjadi berubah. Lewat istilah normal yang baru (new normal), kita mengatur ulang gaya hidup kita. Dari sistem pendingin yang berubah menjadi arena tukar-menukar pengetahuan melalui sistem dalam jaringan, bekerja di rumah melalui sambungan internet, hingga berubahnya pola peribadatan sebab segala ekspresi yang berkenaan dengannya mesti selalu patuh terhadap protokol kesehatan.

Sebaran pasien virus Covid-19 dan bagaimana dinamika ekspresi umat beragama, bisa kita analisis berdasarkan konteks area. Secara statistik, wilayah perkotaan/urban relatif tinggi angka sebarannya. DKI Jakarta, misalnya, stagnan berada di zona merah dengan jumlah akumulatif pasien positif hingga hari ini (27/08) mencapai 24.521 orang. ${ }^{1}$ Hal demikian bisa dipengaruhi oleh pelbagai faktor seperti tingginya kepadatan penduduk, arus mobilisasi, ketersediaan dan kemampuan menjangkau akses kesehatan, interaksi antar personal, hingga kepatuhan penduduk untuk menerapkan protokol kesehatan. Sementara di wilayah pedesaan/rural seolah berlaku sebaliknya. Atas fakta itulah, saya tertarik untuk meninjau sejauh mana perubahan gairah spiritual masyarakat urban di tengah kecamuk wabah. Di Desa, negosiasi antara pentingnya mencegah sebaran virus dan kewajiban melaksanakan ritual agama tampak tak terlalu signifikan. Pertama, karena wilayah mereka cenderung minim pola sebarannya, kedua karena minimnya narasi tandingan yang hadir di tengah masyarakat mengenai wabah, sehingga aktivitas mereka selalu berlandaskan pada sosialisasi dari pusat. Satu-satunya asupan informasi yang dipercaya secara simbolis adalah melalui sosok Kiyai, yang disakralkan sekaligus menjadi Key Opinion Leader kelompok muslim pedesaan.

Kiyai menjadi representasi terhadap wilayah dan ruang, karena dalam alam pikir masyarakat desa ia sering kali dianggap sebagai orang yang diutus untuk memperbaiki akhlak di wilayah tempatan. Dengan begitu, peran kiyai di desa dengan sosok yang

\footnotetext{
${ }^{1}$ https://amp.kompas.com/megapolitan/read/2020/08/27/17093851/update-27-agustus-tambah820-kasus-Covid-19-di-jakarta-tertinggi-selama (diakses 27/08)
} 
multifungsi-sebagai pemuka agama, sekaligus pedoman untuk dimintai pendapatmenjadi lebih di dengar dan mencakup banyak orang. Keluasan pihak-pihak yang mempercayai petuah dan pendapatnya adalah nila lebih untuk mengatur persepsi publik. Terlebih dalam konteks Covid-19. Ini sangat berbalik dengan kiyai dan ulama di mata para penduduk muslim perkotaan, yang begitu kental dengan sajian Islam politik. Pendapatpendapat kiyai hanya bisa diterima oleh kelompok masing-masing, dan tak universal sebab penduduk di kota lebih heterogen dan kompleks, dengan begitu banyak permasalahan.

Kota tidak saja menjadi area hidup dan mencari penghidupan, tetapi menjadi arena yang gegap dengan aneka kontestasi. Kelompok-kelompok agama yang beragam, identitas yang tidak tunggal, membuat mereka senantiasa berlomba-lomba menjajakan eksistensi dan kepengurusannya di tengah publik. Perseteruan wacana ini menarik untuk dikaji, terutama dalam konteks cara mereka memandang wabah Covid-19, dan bagaimana dampaknya terhadap keberlangsungan gairah spiritual. Ilham penelitian ini datang dari kajian-kajian terkait gejala urban sufisme yang beberapa dekade lalu menjadi perdebatan sengit para akademisi.

\section{METODOLOGI}

Metode Penelitian yang digunakan dalam penelitian ini menggunakan metode penelitian kepustakaan dengan pendekatan kualitatif untuk memperoleh data deskriptif yang relevan dengan isu Covid-19. Pengumpulan data yang ditempuh dalam penelitian ini dengan melakukan studi kepustakaan, sumber data penelitian berasal dari sumber-sumber yang telah terdokumentasi dari perpustakaan. Studi kepustakaan yang dimaksud adalah penelitian yang sumber-sumber datanya terdiri atas bahan-bahan tertulis yang telah Dipublikasikan dalam bentuk buku, jurnal ilmiah, surat kabar, majalah dan lain-lain

Dengan menggunakan data-data dari berbagai referensi baik primer maupun sekunder. Data-data tersebut dikumpulkan dengan teknik dokumentasi, yaitu dengan jalan membaca (text reading), mengkaji, mempelajari, dan mencatat literatur yang ada kaitannya dengan masalah yang dibahas dalam tulisan ini.

\section{TEMUAN DAN PEMBAHASAN}

Karena membahas secara umum gairah spiritual masyarakat muslim urban di tengah wabah Covid-19, maka literatur yang menjadi acuan dasar penelitian ini bersumber dari buku-buku dan jurnal ilmiah yang telah secara khusus membahas perihal konsep ruang, geografi, spasial, dan lokasi yang mempengaruhi karakteristik spritual dan agama suatu kelompok masyarakat.

Buku pertama yang dijadikan sumber rujukan-primer source-adalah buku berjudul Sufism and The Modern in Islam (I.B.Tauris \& Co Ltd, London, 2007), yang disusun oleh Martin van Bruinessen dan Jullia Howel, sebab apa-apa yang tercantum dalam buku itu berhasil meyakinkan kita bahwa Sufisme di Indonesia-dan negara Islam lainnya-memiliki makna yang lebih luas sebagai bagian tak tersentuh dari tren global, dengan basis pengetahuan teoritis yang belum sepenuhnya terdaftar dalam sosiologi Islam 
dan pemahaman populer kontemporer-sebagaimana harapan yang mereka catat di kata pengantar.

Proyek penyusunan buku tersebut diinisiasi oleh Azyumardi Azra, Rektor Institut Agama Islam Negeri (IAIN), sekarang diinisiasi Islam Negeri (UIN) Syarif Hidayatullah di Jakarta, dan peneliti Pusat Studi Islam dan Masyarakat (PPIM). Buku tersebut menjadi tonggak munculnya perdebatan sengit mengenai urban sufisme, dan membuka banyak kajian mendalam tentangnya, termasuk di Indonesia sendiri.

Tulisan Luthfi Makhasin berjudul Urban Sufism, Media and Religius Change in Indonesia, misalnya. Dalam penelitian ini digunakan sebagai peletak dasar untuk meninjau sebaran informasi dan dakwah masyarakat muslim kota. Pola penggunaan internet sebagai medium baru adalah hal yang menarik untuk diteliti, terlebih di tengah wabah Covid-19 penerapan sistem Pembatasan Sosial Skala Besar (PSBB) membuat aktivitas harian berubah menuju ranah virtual. Tulisan Ken Miichi, berjudul Urban Sufi and politics in contemporary Indonesia: the role Of dhikr associations in the anti-'Ahok, membuka wawasan kita terhadap rasa kebersamaan masyarakat urban.

Sumber-sumber lain, yang membabar relasi ruang, area, tempat dan hubungannya dengan eskpresi spiritual, dijadikan acuan penting. Antara lain buku berjudul Design for Ecological Democracy (Cambridge: MIT Press, 2006), yang ditulis oleh Hester. Juga artikel publikasi ilmiaj yang ditulis oleh L Kong, dengan judul Geography and Religion: Trends and Prospects.

Sementara untuk wabah, data-data faktual dari media daring yang terpercaya dijadikan sumber rujukan sebagai kontekstualisasi. Sementara penerapan, pengertian, dan hal-hal yang berkenaan dengan istilah teknis dirujuk langsung dari sumber terpercaya yaitu laman organisasi kesehatan dunia (WHO).

\section{Karakteristik Masyarakat Urban}

Lebih dari setengah populasi dunia tinggal di wilayah perkotaan. Pada tahun 2050, diperkirakan oleh demografi terkemuka, hampir tujuh puluh persen populasi masyarakat dunia akan tinggal di kota. Hal ini berkenaan dengan proses urbanisasi dan modernisasi yang kian pesat. Hal ini juga ditandai dengan semakin hancurnya batas-batas identitas kebudayaan suatu bangsa. Kamus Merriem Webster mendefinisikan masyarakat urban sebagai; masyarakat yang khas dari peradaban industri modern dengan heterogenitas tinggi dalam tradisi-budaya, yang lebih mengutamakan nilai-nilai sekuler, bersifat individual dan tidak terintegrasi - kontras dengan masyarakat rural.

Para ahli telah mengemukakan pendapatnya kepada umum perihal definisi masyarakat urban. Pendapat mereka relatif tidak jauh berbeda, pada intinya sepakat untuk memberi prasyarat seseorang sebagai masyarakat urban-selain karena tinggal di wilayah perkotaan—adalah dengan melihat sikap dan karakternya, sebagaimana berikut;

- Jarak Sosial

Jarak sosial adalah penjumlahan dari anonimitas dan heterogenitas. Sebagian besar kontak sosial di kota bersifat impersonal dan segmented. Di masyarakat perkotaan, respon terhadap isu sosial seringkali tidak lengkap dan setengah hati. Keterlibatan pribadi sangat kurang.

- $\quad$ Sistem interaksi: 
Georg Simmel berpendapat bahwa struktur sosial masyarakat perkotaan didasarkan pada kepentingan. Lingkaran kontak sosial memang lebih luas di kota daripada di pedesaan, namun itu tidak menunjukkan adanya keterikatan. Hal ini membuat kehidupan kota menjadi lebih kompleks dan bervariasi. Kehidupan kota dicirikan oleh dominasi kontak sekunder, hubungan impersonal, kasual dan berumur pendek.

- Mobilitas:

Ciri terpenting masyarakat perkotaan adalah mobilitas sosialnya. Di wilayah perkotaan, status sosial seseorang ditentukan bukan oleh keturunan atau kelahiran, tetapi oleh prestasi, kecerdasan, dan ketekunannya.

- Materialisme:

Dalam masyarakat perkotaan, keberadaan sosial manusia berkisar pada kekayaan dan harta benda. Nilai seorang masyarakat tidak dinilai dari apa adanya, melainkan dari ada apanya. Simbol status berupa aset keuangan, gaji, peralatan rumah tangga yang mahal banyak diperhitungkan.

- Individualisme:

Kebanyakan kaum urban sangat mementingkan kesejahteraan dan kebahagiaan mereka sendiri. Mereka ragu untuk berpikir atau bertindak demi kebaikan orang lain.

- Rasionalitas:

Dalam masyarakat perkotaan ada penekanan pada rasionalitas. Orang cenderung bernalar dan berdebat. Hubungan mereka dengan orang lain sebagian besar diatur oleh pertimbangan untung atau rugi. Hubungan terjadi berdasarkan kontrak. Setelah kontrak berakhir, hubungan antar-manusia secara otomatis akan berakhir.

- Anonimitas:

Seperti yang diamati Bogardus, "Kelompok perkotaan memiliki reputasi untuk tidak bernama." Berdasarkan ukuran dan populasinya, masyarakat perkotaan tidak bisa menjadi kelompok utama. Di sini tidak ada yang mengenal siapa pun dan tidak ada yang peduli pada siapa pun. Kadang-kadang, penduduk kota tidak peduli dengan tetangganya dan tidak ada hubungannya dengan kesengsaraan atau kesenangan mereka.

- Kontrol sosial formal:

Kontrol sosial dalam masyarakat perkotaan pada dasarnya bersifat formal. Perilaku individu diatur oleh badan-badan seperti polisi, penjara, pengadilan, dll.

- Profesi

Di daerah perkotaan, pekerjaan utama adalah industri, administrasi dan pekerjaan profesional. Divisi tenaga kerja dan spesialisasi pekerjaan sangat umum terjadi di kota metropolitan. Kriteria tersebut mempengaruhi corak spiritual suatu kelompok masyarakat. Selain pengaruh geografis, cerminan masyarakat dan pola peribadatan sejatinya memang didorong oleh banyak hal. Oleh sebab itu, dengan perbedaan yang begitu distingtif dan nyata, masyarakat urban jauh berbeda dengan masyarakat rural. 


\section{Gairah Spiritual dan Negosiasi Terhadap Dinamika Mutakhir}

Konsep agama, simbol dan praktik telah menjadi bahasan utama di media dan budaya populer, sehingga agama sebagai suatu masalah telah menemukan jalannya dalam perdebatan tentang identitas, warisan, marjinalitas kaum minoritas, masalah kesetaraan dan layanan sosial berbasis agama. Di samping bangkitnya sekularisme, kota adalah arena utama di mana suara para penganut agama - melalui, misalnya, mode pakaian, bangunan, pola dakwah, ritual dan pertunjukan-ditampilkan dan dibahas. Di kota, dan semakin banyak di pinggiran kota, orang dan kelompok religius menanggalkan dan mereproduksi bukti material eksistensi mereka. ${ }^{2}$

Tempat ibadah dan situs keagamaan lainnya, yang dibuat khusus atau didaur ulang, permanen atau sementara, telah dibangun untuk memenuhi kebutuhan komunitas atau jaringan masyarakat muslim urban yang berkembang. Yang sangat penting untuk kita tinjau adalah keterlibatan mereka dengan jejak material dari masa lalu. Kasus ini terlihat dalam praktik menjadikan masjid Istiqlal sebagai situs wisata religi. Mereka melangsungkan ibadah, sekaligus melancong. Situs semacam itu, dan lainnya adalah manifestasi spasial dan material dari situs dan ruang yang disakralkan di wilayah perkotaan.

Wacana tentang tata ruang kota pasca-sekuler telah membuka perdebatan yang lebih umum mengenai konsep hegemoni. Konsep pasca-sekularisasi itu sendiri menyarankan kita bergeser dari sekularisasi masa kini, dengan asumsi implisit yang dimiliki modernitas menjadi sekuler dalam artian 'kekecewaan terhadapdunia'. Hal ini berkaitan dengan kebangkitan kembali kepercayaan, iman dan kesucian sebagai fenomena kolektif, sedangkan gagasan kota postsecular menunjukkan kembalinya kot sebagai ruang di mana dinamika perubahan agama-sekuler terungkap dan diekspresikan sebagai identitas. (Baker dan Beaumont, 2010).

Ruang sakral atau alam yang dianggap keramat, adalah tempat yang diberkahi oleh komunitas masyarakat atas dasar keyakinan, nilai dan kebajikan yang sangat dihormati dan diterapkan secara bersamaan. Keyakinan, nilai, dan kebajikan ini ditunjukkan melalui ritual penggunaan tempat-tempat tersebut. Kualitas dari pengalaman yang hadir berkisar dari metafisik (seperti transendensi, iman, dan harapan) praktis (seperti empati, ketenangan dan amal) dan duniawi (seperti kearifan lokal, rasa kebersamaan, dan orientasi). ${ }^{3}$

Mereka mewujudkan suatu hubungan antara dirinya dan yang ilahi. Dalam pengertian ini, mereka adalah pintu masuk yang sangat baik untuk mempelajari dinamika agama di Kota. Beberapa orang melihatnya sebagai ekspresi positif atas multikulturalisme perkotaan, atau produk kebebasan dan kesetaraan yang diperlukan; orang lain menganggapnya sebagai tanda merebaknya Islamisasi di tengah masyarakat, atau sebagai bukti bahwa agama mendapatkan kembali landasan dalam kehidupan publik.

Pandangan seperti itu datang dalam debat publik dan liputan media, misalnya ketika berita tersebar bahwa ada rencana untuk membangun terowongan toleransi di masjid Istiqlal, sebagai cerminan penerimaan multikulturalisme dari negara. Masjid sebagai satu reka bangunan, tampaknya diperhatikan dan dijadikan simbol dan tanda ketaatan suatu masyarakat. Orang-orang kota-bahkan dalam titik ini, orang desa juga

${ }^{2}$ Dwyer dkk. Faith and Suburbia: Secularisation, Modernity and the Changing Geographies of Religion in London's Suburbs. (Transactions of the Institute of British Geographers, 2013) halaman 38

${ }^{3}$ Hester, Design for Ecological Democracy. (Cambridge: MIT Press, 2006) halaman 117 
mempraktikkannya-berlomba-lomba membangun gedung masjid dengan nuansa termewah, dengan ornamen khas, sebab dengan demikian mereka merasa bangga dan terwakili oleh masjid sebagai simbol dan tanda.

Plato telah memberikan argumentasi dasar untuk kita gunakan sebagai gagasan "tanda." Dalam bukunya The Sophist, diceritakan tokoh bernama Theaetetus berdebat

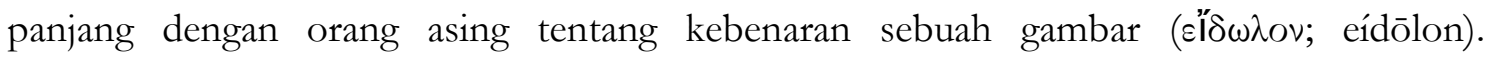
Perdebatan itu digambarkan begitu mengalir dan indah. Setelah membahas aspek imitasi, rupa, realitas dan ilusi, orang asing itu tampaknya bingung dan kemudian melempar satu pertanyaan filosofis: "Lalu apa yang kita sebut sebagai rupa [cirióv; eikōn], meskipun tidak pernah benar-benar nyata, benarkah ia ada?" Jawaban Theaetetus: "Tidak, kita tampaknya telah terlibat

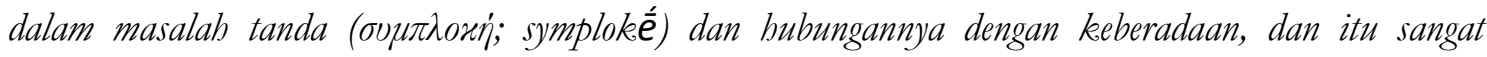
absurd". ${ }_{4}$ Jadi, dalam dialog singkat tersebut kita memiliki gambaran betapa paradoksnya tanda, presentasi, representasi, dan eksistensi.

Penelitian tentang gairah spiritual masyarakat urban, disandarkan pada fakta maraknya pembangunan tempat ibadah di ruang perkotaan—dan pinggiran kota—sebagak indikasi kebangkitan islamisme dan hubungannya dengan globalisasi dan neoliberal. Kota, sebagaimana kita tahu, adalah pusat dari dua arus tersebut. Sesaat setelah Pemerintah Provinsi memberikan inisiatif Penerapan Pembatasan Sosial Berskala Besar (PSBB) di DKI Jakarta, Masjid Raya Istiqlal belum menggelar pelaksanaan salat Jumat dan ritual kunjungan lainnya. Hal ini sebagai upaya pihak pengurus agar penularan virus Covid-19 tidak kian masif.

Penutupan masjid yang dicetuskan oleh pihak kementerian agama ternyata mendapatkan tentangan dari pelbagai pihak. Masjid sebagai ruang berkumpul dan beribadah, begitu disakralkan oleh umat muslim. Kelompok organisasi Front Pembela Islam (FPI) bahkan tak sungkan untuk menuding pemerintah sedang mencari kambing hitam atas datang dan nyebarkan Virus Corona (Covid-19).

Sekretaris Umum FPI Munarman mengatakan dari awal pemerintah tidak punya rencana yang jelas dalam penanganan Corona. Wacana ini, katanya, hanya menambah ketidakjelasan visi pemerintah. "Sekarang jadi enggak jelas karena kebijakan tidak jelas, dan penguasa sedang mencari cari kambing hitam untuk dipersalahkan dalam pandemik ini. Dan yang akan dijadikan kambing hitam lagi-lagi umat Islam." ${ }^{5}$ Fakta ini menggemakan indikasi adanya proses generalisasi terhadap satu kelompok masyarakat dan juga terhadap simbol tertentu. Wacana yang beredar belakangan diekspresikan dalam pertumbuhan bentuk-bentuk agama yang diberi label sebagai fundamentalis atau konservatif, dan terkadang menjadi pembahasan yang menarik juga memiliki pengaruh lebih luas ketimbang bentuk agama yang dianggap liberal atau menjadi arus utama.

Beberapa analisis Kong (1990, 1993, 2001) yang mengembangkan gagasan ruangruang agama yang tercermin dalam konsep geografi agama tampaknya sangat relevan dengan kasus di Jakarta. Dia menekankan bahwa upaya menyelidiki batas-batas ruang agama-sekuler di kota telah menjadi topik yang menonjol dalam studi geografi agama pada

\footnotetext{
${ }^{4}$ Plato, Theaetetus - Sophist, diterjemahkan oleh H. N. Fowler. (London: W. Heinemannand G. P. Putnam's Sons, 1921) halaman 351

${ }^{5}$ https://m.cnnindonesia.com/nasional/20200512172711-20-502632/fpi-kritik-keras-ide-menagfachrul-razi-soal-relaksasi-masjid (diakses 20/09)
} 
1980-an dan 1990-an, dengan penekanan pada pemetaan sebaran kelompok agama di seluruh ruang, dan di titik waktu tertentu. ${ }^{6}$

Meleburnya banyak masyarakat dengan latar yang kian beragam di Kota, dengan pertumbuhan populasi yang padat dam masifnya perpindahan penduduk dari kampung ke Kota untuk tujuan mencari nafkah-bahkan belakangan juga masuknya tenaga kerja asing sebagai respons pasar global, membuat keberagaman budaya di kota kian pesat. Ini bukan saja membawa dampak fluktuasinya gaya hidup, tetapi juga membuka celah ketimpangan dan penerimaan atas perbedaan.

Tariq Modood pernah mendefinisikan multikulturalisme sebagai pengakuan oleh kelompok mayoritas-dalam konteks Indonesia adalah penduduk muslim-terhadap kelompok yang berbeda dalam ranah publik, hukum, kebijakan, wacana demokrasi, istilah kewarganegaraan, dan identitas nasional. ${ }^{7}$ Sebagaimana kita tahu, masyarakat Indonesia terbangun atas jejaring multikulturalisme yang berusia hampir lebih tua ketimbang usia 'Negara, jika hendak menarik lebih jauh hingga masa pra-kolonialisme, Indonesia telah menjadi pusat perdagangan dunia dan didatangi oleh pelbagai suku di Dunia. Tetapi hingga detik ini, adopsi kebijakan terhadap perbedaan ini menyiratkan respon normatif belaka terhadap fakta perbedaan etnis dan budaya. Keragaman dijunjung dan dirayakan, tetapi dengan pendekatan pragmatis dan non-preskriptif terhadap implikasi perbedaan tersebut.

Semenjak 6 tahun terakhir, utamanya pasca pemilu 2014, perubahan signifikan telah terjadi di dalam interaksi sosial kita. Rasisme dan konflik yang disulut oleh perbedaan etnis kembali memuncak, sebagian ahli berpendapat bahwa ini adalah sisa dari pertikaian politik yang tak berkesudahan.

Kasus yang paling signifikan secara politis dalam skala nasional, tetapi dipicu oleh masyarakat urban, adalah serangkaian aksi unjuk rasa yang disebut Aksi Bela Islam. Dimulai sejak Oktober 2016. Aksi unjuk rasa, yang diorganisir oleh para pemimpin Islam, memprotes tuduhan 'penistaan agama' yang dibuat oleh gubernur Jakarta beragama Kristen dari etnis Tionghoa, Basuki Tjahaja Purnama alias Ahok.

Pada rapat umum terbesar 2 Desember 2016, ratusan ribu orang berkumpul di sekitar Monumen Nasional (Monas). Padahal para Islamis itu, diwakili oleh 'Habib' Rizieq Shihab sebagai ketua FrontPembela Islam (FPI), adalah kelompok kecil yang bahkan terpinggirkan, tetapi kemudian mereka berhasil memobilisasi Muslim urban, dalam skala yang begitu besar, hal ini belum pernah dilakukan sebelumnya. Dengan dilengkapi oleh yurisprudensi Islam, masyarakat muslim perkotaan dianggap lebih baik dalam urusan 'membela Islam'. Keadaan ini menjaga kesetiaan aliansi selama demonstrasi anti-Ahok selesai. ${ }^{8}$ Kita boleh tak setuju pada gerakan itu, tetapi sebagai fenomena ia begitu menarik.

Pertikaian politik tersebut kebanyakan bersumber di internet, kebisingan yang merajalela melalui tagar dan kampanye untuk mengikatkan kebencian (bate speech). Bagi penduduk kota, penggunaan internet memang menjadi pola hidup, malahan menjelma kebutuhan primer yang tak bisa lagi digantikan. Mereka bukan sekadar menggunakan media

${ }^{6}$ Kong, 'Geography and Religion: Trends and Prospects', (Progress in Human Geography, 1990) halaman 14

7 Modood, 'The Place of Muslims in British Secular Multiculturalism. (Oxford: Lexington Books, 2007) halaman 2

${ }^{8}$ Ken Miichi, Urban Sufi and politics in contemporary Indonesia: the role Of dhiker associations in the anti-'Ahok' rallies,(South East Asia Research, 2019) halaman 14 
berbasis jaringan tersebut sekadar untuk melangsungkan komunikasi, tetapi juga melakukan kerja dakwah dan sebaran wacana.

Sejak akhir 1990-an, bersamaan dengan tumbangnya rezim orde baru yang otoriter dan maraknya pemakaian internet di tengah warga, publikasi online telah memainkan peran penting dalam menyebarkan gagasan Islam di Indonesia-baik yang coraknya tradisional maupun modern. Semuanya menggunakan internet sebagai media dakwah. $\mathrm{Pal}$ ini disebabkan karena internet memiliki kelebihan aksesibilitas yang tinggi, juga keterhubungan secara global tanpa sekat-sekat geografis. Orang-orang di Kota Medan bisa menikmati dengan leluasa sajian dakwah dari Masyarakat Muslim Urban di Jakarta, dengan bermodalkan internet, signal, dan gawai yang menunjang. Sebaran dakwah kian masif, dan tak lagi berpatok pada proses mendatangi pintu-pintu (door to door).

Dakwah melalui media tulisan dan lisan menjadi dua cara utama yang digunakan oleh kelompok muslim urban dalam mengkonstruksi wacana Islam populer juga keberlangsungan eksistensi komunitas mereka. Kini kebanyakan dari mereka mengambil bentuk publikasi online di internet (website, sosial media, dan platform digital lainnya), sementara pada beberapa dekade lalu melalui cetakan fisik dalam bentuk buku, jurnal, dan pamflet. Sementara penyampaian melalui lisan banyak dipraktikkan melalui khutbah Jumat, dakwah yang dilakukan pemimpin agama ke tiap pelosok daerah, mengii siraman rohani di acara televisi (lihat acara Mamah dan Aa yang popularitas kian menanjak dan seolah tak tergantikan) atau membuat konten-konten edukasional di platform seperti YouTube yang pada dasarnya menyasar kelas menengah di perkotaan-meski orang-orang Desa juga menjadi konsumen, tetapi jumlahnya tetaplah timpang.

Aktivitas yang memaksimalkan internet bisa kita buktikan dengan banyaknya afiliasi yang hadir secara masif di dunia Maya, baik dalam bentuk situs domain berlangganan atau blog gratis, (Lutfi Makhasin:2016);

Para murid berusia muda menganggap internet sebagai media yang menarik untuk materi tertulis milik Naqsybandi-Haqqani. Situs web dan blog ini dipelihara oleh pemuda yang memiliki minat untuk menerjemabkan ajaran Naqsybandi-Haqqani. Dengan demikian, mereka menjadi situs kreatif di mana para pemuda dapat berekspresi sesuai dengan afiliasi dan sifat religiusitas-sufistik mereka. Saat ini ada sekitar 27 situs web dan blog yang dikelola oleh murid Naqshbandi-Haqqani di Indonesia. Kebanyakan dari menampilkan dakwab terbaru dari Syekh Nazim dan Hisham Kabbani, juga menyebarkan ajaran Naqsybandi-Haqqani dan informasi lain yang berkenaan dengan aktivitas Naqshbandi-Haqqani. Hal tersebut termasuk unggahan gambar, video, nasibat / konsultasi, dan jadwal kegiatan yang akan dilakukan oleb masing-masing zawija dan juga memberikan update informasi mengenai rencana perjalanan Syekh Hisham Kabbani dan rombongannya di Indonesia ${ }^{10}$.

Di masa pandemi, ketika pemerintah mengeluarkan dekrit untuk membatasi interaksi fisik (phisycal distancing), pengoperasian internet semakin dioptimalkan sebagai media berdakwah. Masyarakat urban yang pada dasarnya terisolasi dengan dunia sekitar, sebagai dampak dari aktivitas kerja yang padat, justru semakin leluasa karena mendapatkan sajian rohani tanpa perlu datang ke mesjid atau panggung-panggung dakwah. Internet memperlancar transfer wacana dan narasi keagamaan.

Kota-kota menjadi sasaran penetrasi masuknya wacana keagamaan, bukan hanya karena sebagian besar suku bangsa yang dulu terpencil dan menetap di pedesaan, sekarang

\footnotetext{
${ }^{9}$ Luthfi Makhasin, Urban Sufism, Media and Religius Change in Indonesia. (Ijtimā’iyya, Volume 1, Number 1, September 2016) halaman 24

${ }^{10} \mathrm{Ibid}$
} 
memiliki perwakilan di kota. Mereka juga menjadi sasaran utama, karena kota memiliki banyak kelompok sosial yang belum terjangkau secara merata oleh ajaran agama.

Kota adalah pusat dominasi kapitalisme, dan oleh karena itu menjadi penentu kecepatan masyarakat. Kota, kini tidak lagi semata-mata menjadi pusat geografis untuk perdagangan, pasar tempat manusia menjajakan kelimpahan bumi dan hasil-hasil budayanya. Sebaliknya, kota telah menjadi pusat administrasi yang menyediakan kesejahteraan dan bantuan bagi orang-orang dalam kesulitan. ${ }^{11}$

Agama dan spiritual, pada hakikatnya, mengajarkan kedamaian dan cinta. Sementara itu dominasi, penindasan dan ketidakadilan adalah produk dari kebencian dan kekerasan yang merebak di kota. Angka perkosaan, pembunuhan, penculikan, penipuan, dan segudang kasus kriminal tumbuh subur di kota. Secara radikal, akar permasalahannya boleh jadi merujuk pada angka kemiskinan. Tetapi, orang-orang masih percaya bahwa segala tindak kejahatan bisa dihalau oleh laku spiritual.

Kekerasan dan marjinalisasi tidak hanya lahir dari maldistrubusi hak hidup. Dalam analisis yang berfokus pada penindasan, dominasi dan keadilan, hal itu akan tampak nyata. Namun sering kali analisis tersebut gagal untuk menghubungkan sumber pengharapan dan transformasi spiritual kita yang paling jelas dan kuat kala menghadapi kebencian dan kekerasan: cinta. $^{12}$

Dalam keadaan wabah yang membawa tekanan, wacana keagamaan punya kesempatan lebih luas untuk mengedarkan eksistensinya. Bagaimana pun, secara naluriah setiap manusia selalu membutuhkan satu pengharapan sekaligus pedoman, dan agamasering kali tak kita sadari-menyodorkan dua hal tersebut. Ketimbang pemahaman politik, ekonomi, gender, agama lebih leluasa mempromosikan dirinya sebab ia bekerja di tataran abstraksi. Ini menunjukkan bahwa wabah sebagai bencana nasional—bahkan global—tidak meruntuhkan gairah untuk berbagi pengetahuan dan berdakwah, fenomena virus tersebut hanya mengubah dan menggeser pola dan implementasi beragama. Negosiasi antara dinamika mutakhir dan letak geografis tampil ke permukaan secara nyata, kita bisa menarik tegangan yang sering kali memisahkan-secara ekstrem-antara agama dan bentang wilayah, seolah-olah keduanya tak memiliki singgungan sama sekali.

Menariknya adalah, pertemuan di ranah maya (virtual meeting) memiliki kesempatan nyata untuk menjadi tradisi di tengah masyarakat perkotaan-bahkan boleh jadi setelah bencana wabah selesai. Ini akan menjadi tipikal khas dari kelompok mereka, dan kian menambah jurang pemisah dengan kelompok muslim di pedesaan.

Bagi masyarakat rural, bertemu dengan pemuka agama secara langsung bukan sekadar untuk tujuan mengkaji khazanah pengetahuan agama, tetapi juga sekaligus ngalap berkah. Kiyai, bagi mereka, adalah representasi dari ruang dan alam-para pemuka agama sering dipercaya sebagai salah satu keajaiban yang diturunkan Tuhan untuk membimbing wilayah tertentu. Pengaruh kiyai yang melewati batas-batas geografis pedesaan berkat legitamisi masyarakat untuk memimpin upacara-upacara keagamaan, adat dan menginterpretasi doktrin-doktrin agama. Selain itu seorang kiyai dipandang memiliki kekuatan-kekuatan spiritual karena kedekatannya dengan Sang Pencipta. Kiyai dikenal tidak

${ }^{11}$ Greenway, R. S., and Monsma, Cities: Missions New Frontier. (Baker Books, 1989) halaman 20

12 Porter, Unlearning the Colonial Cultures of Planning. (Aldershot: Ashgate, 2010) halaman 238 
hanya sebagai guru di pesantren, juga sebagai guru spiritual dan pemimpin kharismatik masyarakat. ${ }^{13}$

\section{Wacana Urban Sufisme dan Negosiasi}

Penelitian sosiologis yang digelar pada dekade 1950-an lalu menunjukkan adanya dua pola kepercayaan yang saling bersinggungan, terutama dalam urusan ritual, di antara penduduk Jawa yang mayoritas Muslim. Jurang pemisah itu, pada hakikatnya, tidak saja menjadi kalsifikasi penting mengenai keseharian beragama, tetapi juga menunjukkan kompleksitas yang inheren.

Pembagian ini kemudian secara luas disebut sebagai santri dan abangan, istilah yang dipilih oleh seorang peneliti Amerika untuk mendeskripsikan pola tersebut. (Geertz, 1960). Santri adalah kelompok Muslim yang taat pada syariah, melaksanakan shalat, dan memiliki ikatan dengan-baik secara struktural maupun tidak—tokoh pemuka agama, berdoa secara teratur, berpuasa selama Ramadhan, dan lain sebagainya. Sementara abangan memegang keyakinan sinkretis serta melaksanakan berbagai ritual, misalnya dalam bentuk ritual selametan, mempersembahkan sesajian kepada roh, dan makan bersama.

Meskipun Geertz mengamati dengan teliti bahwa satu orang yang sama dapat bertindak sebagai santri pada beberapa kesempatan, juga sebagai abangan pada kesempatan lain, ia kemudian menggunakan istilah ini sebagai referensi untuk pembedaan kategori sosial. Dengan Indikator ini, setidaknya kita dapat menarik kesimpulan tak kurang dari separuh Muslim Indonesia sebenarnya santri. Tetapi, ada juga varietas lain dadi masyarakat urban dan elit dari budaya sinkretistik ini (yang untuknya, Geertz menggunakan istilah priyayi). ${ }^{14}$

Tiga kelompok masyarakat ini, mayoritas tergabung dalam organisasi keagamaan. Satu-satunya gerakan paling berpengaruh yang didirikan untuk membela islam 'tradisionalis' di Indonesia adalah Nahdlatul Ulama (NU), organisasi yang lahir pada tahun 1926. Dengan demikian, NU mempertahankan bentuk ajaran dan amalan Islam yang mengakui otoritas empat madhhab (mazhab hukum islam), karismatik dan otoritas para ulama, pentingnya berziarah, dan validitas etika dari ritual sufi lainnya. Hadirnya organisasi yang mempertahankan corak keagamaan tradisional, membuat pemahaman ini langgeng di tengah masyarakat. Dan seiring berkembangnya waktu, ajaran tersebut bermutasi seturut perkembangan zaman. Dalam konteks masyarakat urban, hal itu didorong oleh kuasa modal dan kapitalisme yang mulai menggila sejak periode akhir abad sembilan belas. Dan, atas respons, kita mengenal istilah Neo-sufisme.

Penggunaan pertama kali istilah 'Neo-Sufisme' dalam wacana keagamaan, dicetuskan oleh sejarawan dan pemikir berkebangsaan Pakistan, yakni Fazlur Rahman, ${ }^{15}$ ketika ia berusaha memberikan mendeskripsikan dan konteks pola gerakan reformasi sufistik pada periode kedelapan belas dan kesembilan belas.

Secara luas istilah neo-sufisme, atau urban sufisme, dikembangkan oleh Julia Howell. Ajaran tasawuf, dalam berbagai manifestasinya, telah berperan menjadi bagian

\footnotetext{
${ }^{13}$ Mohamad Hudaeri, Tasbih dan Golok; Kedudukan dan Peran Kiyai dan Jawara di Banten. Al-qalam Vol. 20, No. 98, 99 (Juli - Desember 2003) halaman 142

${ }^{14}$ Martin van Bruinessen, Saint, Politicans and Sufi Bureaucrats: Mysticism and Politicks in Indonesia's New Order, dalam buku Sufism and The Modern in Islam. (I.B.Tauris \& Co Ltd, London, 2007) halaman 93

15 O’Fahey, DS and Radtke, Neo-Sufism Reconsidered', (DDe Islam, 1993) halaman 55
} 
penting dalam mengakomodasi peningkatan komitmen terhadap kesalehan, dan menjadi dimensi yang begitu menonjol dalam kisah kebangkitan Islam di Indonesia.

Sufisme juga memiliki kontribusi dalam mediasi religiusitas yang terkait antara Islam Tradisionalisme dan Modernisme. Oleh karena itu, tasawuf membantu menciptakan kesamaan hak Masyarakat sipil di mana ketegangan politik, begitu akut dalam periode sejak jatuhnya Rezim Suharto.Urban Sufisme bagi Howell, sangat beririsan dengan liberalisme Neo-Modernis, bukan hanya karena sering dianut oleh pemikir yang sama, tetapi karena praktik Neo-Sufi, dengan penekanannya pada koneksi yang bersifat ilahiah, menjadi dasar resep sosial etis, dan sangat memperkuat toleransi untuk pluralisme agama. ${ }^{16}$

Howell dianggap melakukan oversimplifikasi, dalam tataran doktrinal dan ritual. Lebih-lebih tradisi praktik dalam dimensi sufisme yang luas dan mendalam. Sebagai Seorang outsider, Howell memang lebih melihat fenomena yang disebutnya Urban Sufism sebagai gejala sosiologis. Mungkin saja, ia hanya melihat fenomena yang nampak pada level permukaan tanpa memahami dimensi instrinsik subtansial sufisme. Prinsip partisipatory menjadi salah satu kata kunci dalam memahami sufisme. Karena itu, ia Dirasa kurang mampu memahami dimensi ajaran maupun praktik pada "jantung" dimensi sufisme itu sendiri. ${ }^{17}$

Dalam studi tasawuf kontemporer di dunia Muslim, istilah Neo-Sufisme umumnya digunakan untuk menggambarkan kelompok yang tersubordinasi dari kalangan sufi konvensional. Amalan sufi seperti itu yang tidak diberi bimbingan langsung dari Mursyid, dan tidak mendapatkan otoritas formal untuk mencari murid spiritual, dianggap bermasalah. Banyak kelompok yang tidak setuju, bahkan menganggap praktik itu berbahaya. Memang demikianlah praktik sufi yang beredar di kota-kota besar seperti ibu kota Jakarta, mereka mereproduksi metode dan ritus baru untuk tersambung secara langsung dengan warisan Sufi konvensional, dan kelompok ini biasanya disebut Sufisme perkotaan (urban Sufism). ${ }^{18}$

Menurut Hakiem (2000) pada awalnya, lahirnya sufisme perkotaan adalah buntut dari pesta perayaan menyambut milenium baru. Dengan hadirnya eksotisme, hedonisme, dan dehumanisme orang dihadapkan pada tantangan baru gejala globalisasi, yang pada generasi sebelumnya tak ada. Gejala spiritual menjadi semacam respons alamiah satu kelompok masyarakat yang tengah terguncang oleh problem baru-yang terasing dari ritus keseharian. Mereka berkumpul, dengan tujuan mencari seberkas cahaya yang menyinari gohong-gohong besar di lubuk hati masingmasing, setelah dalam aktivitas kerja sehari-hari ditekan oleh gencatan Aris globalisasi yang kian pesat.

"Faktanya adalah, ketika pengarub desa menjadi semakin kecil, solusi yang ditawarkan kepada umat manusia tidak otomatis lebih sederhana, tetapi malah jaub lebih kompleks. Kehidupan menjadi semakin gersang dan akbirnya, semakin jauh dari oasis dan hanya menjadi ilusi semu. Neraka dunia menjadi penjara bagi jiwa-jiwa yang lelah. Dengan itu, dunia Sufisme

\footnotetext{
16 Julia Howell, Sufism and the Indonesian Islamic Revival. (The Journal of Asian Studies, 2001) halaman 701

17 Rubaidi, Reorientasi Ideologi Urban Sufism di Indonesia Terhadap Relasi Guru dan Murid dalam Tradisi Generik Sufisme Pada Majelis Shalawat Muhammadiyah Surabaya. (Teosofi: Jurnal Tasawuf dan Pemikiran Islam, 2015) halaman 295

${ }^{18}$ Julia Day Howell, Introduction, Sufism and Neo-Sufism in Indonesia today. (Review of Indonesian and Malaysian Affairs, vol. 46, no. 2, 2012) halaman 5
} 
menawarkan pelarian dari penjara tersebut melalui surga dari hati dan kedamaian bagi batin dan jiwa. ..."19

\section{DISKUSI}

Karena lahir atas tantangan zaman, urban sufisme akan kian semarak seiring corak kapitalisme berkembang, dan daerah perkotaan dengan industrialisasi dan modernisasi kian kokoh. Hal ini semakin diperkuat dengan fakta semakin merajanya liberalisasi perekonomian — setelah narasi besar sosialisme tumbang pada perang dingin lalu. Urban sufisme, sejatinya tak lebih mimesis dari upaya pencarian dimensi rohani masyarakat perkotaan yang dituntut terasing-baik dari dirinya sendiri, maupun dari hasil produksi kerja.

Wabah Covid-19 hanya mengubah-secara samar-gairah spiritual tersebut. Maraknya PHK, banyaknya pabrik-pabrik yang gulung tikar karena ancaman resesi, dan pola kerja yang meminimalisir interaksi anta manusia, justru punya potensi memperkuat jejaring spiritual tersebut.

Covid-19 bagi masyarakat perkotaan adalah pertarungan signifikansi sekaligus pembuktian eksistensi di tengah tata rung yang jalin-jemalin dengan kemegahan dan hedonisme. Akses terhadap informasi dan komunikasi, kemudahan memperoleh teknologi mutakhir, justru menjadi privilage yang membuat masyarakat ini akan tetap bisa melangsungkan aktivitas keagamaan mereka. Ini menunjukkan bahwa wabah sebagai bencana nasional_bahkan global—tidak meruntuhkan gairah untuk berbagi pengetahuan dan berdakwah, fenomena virus tersebut hanya mengubah dan menggeser pola dan implementasi beragama. Negosiasi antara dinamika mutakhir dan letak geografis tampil ke permukaan secara nyata, kita bisa menarik tegangan yang sering kali memisahkan—secara ekstrem—antara agama dan bentang wilayah, seolah-olah keduanya tak memiliki singgungan sama sekali.

Pertemuan di ranah maya (virtual meeting) memiliki kesempatan nyata untuk menjadi tradisi di tengah masyarakat perkotaan — bahkan boleh jadi setelah bencana wabah selesai. Ini akan menjadi tipikal khas dari kelompok mereka, dan kian menambah jurang pemisah dengan kelompok muslim di pedesaan. Bagi masyarakat rural, bertemu dengan pemuka agama secara langsung bukan sekadar untuk tujuan mengkaji khazanah pengetahuan agama, tetapi juga sekaligus ngalap berkah. Kiyai, bagi mereka, adalah representasi dari ruang dan alam-para pemuka agama sering dipercaya sebagai salah satu keajaiban yang diturunkan Tuhan untuk membimbing wilayah tertentu.

\section{REFERENSI}

Dwyer dkk. Faith and Suburbia: Secularisation, Modernity and the Changing Geographies of Religion in London's Suburbs. (Transactions of the Institute of British Geographers, 2013).

Greenway, R. S., and Monsma, Cities: Missions New Frontier. (Baker Books, 1989).

\footnotetext{
${ }^{19} \mathrm{Ibid}$
} 
Julia Day Howell, Introduction, Sufism and Neo-Sufism in Indonesia today. (Review of Indonesian and Malaysian Affairs, vol. 46, no. 2, 2012).

Julia Howell, Sufism and the Indonesian Islamic Revival. (The Journal of Asian Studies, 2001).

Karta C Geertz, Abangan, Santri, Priyayi Dalam Masyarakat Jawa (Pustaka Jaya, 1981).

Ken Miichi, Urban Sufi and politics in contemporary Indonesia: the role Of dhikr associations in the anti-'Ahok' rallies,( South East Asia Research, 2019).

Kong, 'Geography and Religion: Trends and Prospects', (Progress in Human Geography, 1990).

Luthfi Makhasin, Urban Sufism, Media and Religius Change in Indonesia. (Ijtimā’iyya, Vol. 1, No.1, September 2016).

Martin van Bruinessen, Saint, Politicans and Sufi Bureaucrats: Mysticism and Politicks in Indonesia's New Order, dalam buku Sufism and The Modern in Islam. (I.B.Tauris \& Co Ltd, London, 2007).

Modood, 'The Place of Muslims in British Secular Multiculturalism. (Oxford: Lexington Books, 2007).

Mohamad Hudaeri, Tasbih dan Golok; Kedudukan dan Peran Kiyai dan Jawara di Banten. Al-qalam Vol. 20, No. 98, 99 (Juli - Desember 2003).

O’Fahey, DS and Radtke, 'Neo-Sufism Reconsidered', (DDe Islam, 1993).

Plato, Theaetetus - Sophist, diterjemahkan oleh H. N. Fowler. (London: W. Heinemannand G. P. Putnam's Sons, 1921).

Porter, Unlearning the Colonial Cultures of Planning. (Aldershot: Ashgate, 2010)

Rubaidi, Reorientasi Ideologi Urban Sufism di Indonesia Terhadap Relasi Guru dan Murid dalam Tradisi Generik Sufisme Pada Majelis Shalawat Muhammadiyah Surabaya. (Teosofi: Jurnal Tasawuf dan Pemikiran Islam, 2015).

Randolph Hester, Design for Ecological Democracy. (Cambridge: MIT Press, 2006).

https://m.cnnindonesia.com/nasional/20200512172711-20-502632/fpi-kritik-keras-idemenag-fachrul-razi-soal-relaksasi-masjid.

https://amp.kompas.com/megapolitan/read/2020/08/27/17093851/update-27-agustustambah-820-kasus-Covid-19-di-jakarta-tertinggi-selama. 